\title{
Effect of Foliar Nutrient on Growth, Seed Yield and Quality Parameters in Quinoa (Chenopodium quinoa willd.)
}

\author{
M. S. Navyashree*, Bineeta Michael Bara, Garlapati Mohan Krishna, \\ Kusume Bhanu Rajesh and Gopika Jaypal
}

Department of Genetics and Plant Breeding, Naini Agricultural Institute, Sam Higginbottom
University of Agriculture, Technology and Sciences, Prayagraj, Uttar Pradesh, India

*Corresponding author

\section{A B S T R A C T}

\section{Keyw ords \\ Quinoa, Salicylic Acid, Moringa Leaf Extract, Quality parameters, Vigour and seed yielding attributes}

\section{Article Info}

Accepted: 12 December 2020 Available Online: 10 January 2021
The experiment was conducted in Field Experimentation Centre, Department of Genetics and Plant Breeding, Sam Higginbottom University of Agriculture, Technology and Sciences, Prayagraj (U.P.) during Rabi season 2019-2020, in order to standardize the suitable spraying treatment of Quinoa (variety:- EC 507740). Different spraying treatment with control (Unspraying) were evaluated by screening 45 DAS and 60 DAS viz., $\mathrm{T}_{0}-$ Control, $\mathrm{T}_{1}$ - Urea (2\%) @ 45 DAS, T - DAP (2\%) @ 45 DAS, T - Chitosan (0.5\%) @ 45 DAS, T 4 - Moringa Leaf Extract (3\%) @ 45 DAS, T - Ascorbic Acid (50 ppm) @ 45 DAS, T 6 - Salicylic Acid (10 ppm)@45 DAS, T - Urea (2\%) @60 DAS, T - DAP (2\%)@60 DAS, T - Chitosan (0.5\%) @60 DAS, T $10-$ Moringa Leaf Extract (3\%) @ 60 DAS, $T_{11}-$ Ascorbic Acid (50 ppm) @60 DAS and T 12 - Salicylic Acid (10 ppm) @ 60 DAS. It was found that all the spraying treatments showed significance difference with the control except speed of germination, days to anthesis and biological yield. Foliar application treatment increases the germinability and vigour of quinoa seeds, significantly in both lab and field condition. Spraying with Salicylic Acid 10 ppm @ 45 DAS followed by Chitosan 0.5\%@60 DAS, DAP 2\%@45 DAS, Ascorbic Acid 50 ppm @60 DAS and Urea $2 \% @ 60$ DAS showed maximum increase in germin ability and vigour of quinoa seeds. Foliar application treatment on field and lab condition give best result in Salicylic Acid 10 ppm @ 45 DAS and found to be lowest in Control (untreated). These conclusions are based on the results of six months investigation and therefore further investigation is needed to arrive at valid recommendations. The treatments of quinoa crop with Ascorbic Acid is ecofriendly and economic in use.

\section{Introduction}

Quinoa (Chenopodium quinoa Willd) is a halophytic, allotetraploid grain crop of the Amaranth family with the impressive drought tolerance, nutritional content and an increasing the worldwide market (Risi and Galwey, 1984). The nearest wild species to quinoa are C. hicinum and C. berlandieri, which have the same number of chromosomes $(2 \mathrm{n}=4 \mathrm{x}=36)$, and C. pallidicaule with $2 \mathrm{n}=$ $2 \mathrm{x} 18$ chromosomes. It is dicotyledonous 
annual plant grown as a grain crop primarily for its edible seeds. As it is having high protein content $(14.1 \mathrm{gm} / 100 \mathrm{gm})$ in the grains. It is neglected crop in the past years, now it is gaining popularity due to its many health benefits. It is commonly called as quiuna, parka, dawe, chuppah and kinwah and quinoa is not a grass, but a pseudo cereal botanically related to spinach and amaranth (Amaranthus spp.) Quinoa provides protein, dietary fibre, vitamin B and dietary minerals in rich amounts above those of wheat, corn, rice or oats. It is gluten free, after harvest the seeds are processed to remove the bitter tasting outer seed coat. FAO declared 2013 as International year of

Nutritional characteristics are the result of environmental conditions, such as temperature, light intensity, relative humidity and precipitation. These conditions are key factors in the quality and number of grains per panicle (Morales et al., 2017), as well as in the phonological and physiological performance of the plants related to the adaptive capacity to diverse environmental conditions (Winkel et al., 2016). The plant has adaptive advantages that allow it to express a great productive potential. It is considered a crop with great potential because of its high agronomic characteristics and nutritional value, and especially for its inclusion in children and elderly people's diets (Valcárcel- Yamany and Silva, 2012). According to Escuredo et al., (2014), this plant has the capacity to produce grains of high quality and protein content. Additionally, it contains amino acids such as lysine, threonine and methionine, which are considered as essential.

Crop nutrients are the elements, which are essential in providing healthy and vigorous plants. They initiate all processes which are vital for crop development. Therefore, plant needs nutrients throughout its growing cycle.
Plant nutrients are available in various forms and nutrient ratios. Among the various plant nutrients, whether based on organic or mineral composition, they can be applied to crops by foliar and granular application. By foliar spray plants take nutrients more efficiently through stomata. Application is done when there is lack of particular nutrient in the soil or when the plant roots are not able to absorb the required amounts of nutrients. Ascorbic acid plays role in plant growth and development, cell division, cell wall metabolism and cell expansion, shoot apical meristem formation, root development, photosynthesis, regulation of florescence and regulation of leaf senescence. Also, it is cofactors for enzyme activity, and effects on plant antioxidation capacity, heavy metal evacuation and detoxification and stress defense (Zhang, 2012).

\section{Materials and Methods}

The present investigation was carried using genetically pure seeds of Quinoa (variety:EC 507740). Experiment was conducted in Field Experimentation Centre, Department of Genetics and Plant Breeding, Sam Higginbottom University of Agriculture, Technology and Sciences, Prayagraj (U.P.). The experiment was conducted during Rabi season of 2019-20 in Randomised Block design consisting of 12 combinations with three replications and laid out with different treatments allocated randomly in each replication. $\mathrm{T}_{0}$ - Control, $\mathrm{T}_{1}$ - Urea (2\%) @ 45 DAS, T 2 - DAP (2\%) @ 45 DAS, T Chitosan (0.5\%) @ 45 DAS, T 4 - Moringa Leaf Extract (3\%) @ 45 DAS, $\mathrm{T}_{5}$ - Ascorbic Acid (50 ppm)@45 DAS, T 6 - Salicylic Acid (10 ppm) @ 45 DAS, T 7 - Urea (2\%) @ 60 DAS, T 8 - DAP (2\%) @60 DAS, T9 Chitosan (0.5\%) @60 DAS, T $10-$ Moringa Leaf Extract (3\%) @60 DAS, T 11 - Ascorbic Acid (50 ppm) @60 DAS and $\mathrm{T}_{12}$ - Salicylic Acid (10 ppm) @60 DAS. 


\section{Results and Discussion}

According to the results, all studied traits were affected by the treatments and there was completely significant difference between control (non-spraying seeds) and spraying seeds in Table-2.

Spraying treatment with SA (10 ppm)@45 DAS recorded maximum field emergence percent $(87.00 \%)$ followed by $\mathrm{T}_{9^{-}}$Chitosan (0.5\%) @ 60 DAS (85.67\%), T 2 DAP (2\%) @ 45 DAS $(85.00 \%)$ and $\mathrm{T}_{4}$ - Moringa leaf extract (3\%) @ 45 DAS (84.33\%). Minimum field emergence percentage was recorded by $\mathrm{T}_{0}-$ Control $(78.33 \%)$. The positively effect of spraying treatment on field emergence percentage was found to be significant and similar finding observed by Abbas, (2013); Abbaszadeh et al., (2008); Sivakumar et al., (2002) and Rohamare et al., (2013).

Maximum plant height at $60 \mathrm{DAS}(106.67 \mathrm{~cm})$ was recorded by $\mathrm{T}_{6^{-}} \mathrm{SA}$ (10 ppm) @ $45 \mathrm{DAS}$ followed by $\mathrm{T}_{11^{-}}$Ascorbic Acid (50 ppm) @ 60 DAS $(105.00 \mathrm{~cm}), \mathrm{T}_{2}-\mathrm{DAP}(2 \%) @ 45$ DAS (99.67) and $\mathrm{T}_{9}$ - Chitosan (0.5\%) @ 60 DAS (98.60).Minimum plant height at 60 DAS was recorded by $\mathrm{T}_{0}-$ Control (83.01 $\mathrm{cm})$. Maximum plant height at $90 \operatorname{DAS}(127$ $\mathrm{cm}$ ) was recorded by $\mathrm{T}_{6^{-}} \mathrm{SA}$ (10 ppm) @ 45 DAS followed by $\mathrm{T}_{9-}$ Chitosan $(0.5 \%) @ 60$ DAS (125.00 cm), T $3_{3}$ - Chitosan $(0.5 \%) @ 45$ DAS (123.67) andT ${ }_{11}-$ Ascorbic Acid (50 ppm) @60 DAS (120.67 cm).Minimum plant height at 90 DAS was recorded by $\mathrm{T}_{0}-$ Control $(100 \mathrm{~cm})$. The positively effect of spraying treatment on plant height was found to be significant and similar finding observed by Abd El-Wahab and Mohamad, (2008); ElKeltawi and Croteau, (1987); Vani et al., (2004) and Aishwath et al., (2011).

Number of branches per plant (10.33) was recorded highest inT $6^{-}$SA (10 ppm) @ 45 DAS followed by $\mathrm{T}_{9-}$ - Chitosan (0.5\%)@60
DAS (10.00), T 2 - DAP (2\%) @ 45 DAS (9.70) andT 4 - Moringa leaf extract (3\%) @ 45 DAS (9.67).Minimum number of branches per plant was recorded by $\mathrm{T}_{0}-$ Control (7.00). The positively effect of spraying treatment on number of branches per plant was found to be significant and similar finding observed by El-Tohamy et al., (2007); Verma and Sen, (2008) and Giannakoula et al., (2012).

Total number of panicles per plant (9.67) was recorded highest inT $_{6^{-}}$SA (10 ppm) @ 45 DAS followed by T $_{2}$ DAP (2\%) @ 45 DAS (9.02), $\mathrm{T}_{9^{-}}$Chitosan (0.5\%) @ 60 DAS (9.00) and $\mathrm{T}_{11^{-}}$Ascorbic Acid (50 ppm) @ 60 DAS (8.15). Minimum total number of panicles per plant was recorded by $\mathrm{T}_{0}-$ Control (5.86). The positively effect of spraying treatment on total number of panicles per plant was found to be significant and similar finding observed by Bate et al., (2003); Sivakumar et al., (2002) and El-Sherbeny and Abou Zeid, (1986).

Total number of productive panicles per plant (7.33) was recorded highest $\operatorname{inT}_{6}-\mathrm{SA}(10$ ppm)@45 DAS followed by $\mathrm{T}_{9^{-}}$Chitosan (0.5\%)@60 DAS (7.02), T2- DAP (2\%)@ 45 DAS (6.53) andT $11_{1}$ - Ascorbic Acid (50 ppm) @ 60 DAS (6.10).Minimum total number of productive panicles per plant was recorded by $\mathrm{T}_{0}$ - Control (3.00). The positively effect of spraying treatment on total number of productive panicles per plant was found to be significant and similar finding observed by Aftab et al., (2010); Rathod et al., (2005); Sivakumar et al., (2002) and Tarraf et al., (1999).

Minimum taken days to anthesis (43.33) was recorded by $\mathrm{T}_{11^{-}}$Ascorbic Acid (50 ppm) @ 60 DAS followed by $\mathrm{T}_{6}-\mathrm{SA}$ (10 ppm) @ 45 DAS (43.43), $\mathrm{T}_{9}$ - Chitosan (0.5\%) @ $60 \mathrm{DAS}$ (44.00) and $\mathrm{T}_{8-}$ - DAP (2\%) @60 DAS (44.07). Maximum taken days to anthesis was recorded by $\mathrm{T}_{0}-$ Control (46.02). The positively effect of spraying treatment on 
days to anthesis was found to be nonsignificant and similar finding observed by Bhat et al., (2011); Patel and Vyas, (2007) and Purbey and Sen, (2005).

Minimum taken days to $50 \%$ flowering (46.00) was recorded by $\mathrm{T}_{6^{-}} \mathrm{SA}(10 \mathrm{ppm}) @$ 45 DAS followed byT $2^{-}$DAP (2\%)@ 95 DAS (46.67), $\mathrm{T}_{9^{-}}$Chitosan (0.5\%) @ 60 DAS (47.00) and $\mathrm{T}_{5}$ - Ascorbic Acid (50 ppm) @ 45 DAS (47.33). Maximum taken days to $50 \%$ flowering were recorded by $\mathrm{T}_{0}-$ Control (50.67). The positively effect of spraying treatment on days to $50 \%$ flowering was found to be significant and similar finding observed by Beena and Mercy, (2003) and Kataria et al., (2003);.

Minimum taken days to maturity (86.67) was recorded by $\mathrm{T}_{6}-\mathrm{SA}(10 \mathrm{ppm}) @ 45 \mathrm{DAS}$ followed by $\mathrm{T}_{9^{-}}$Chitosan (0.5\%) @60 DAS (87.33), $\mathrm{T}_{2}$ - DAP (2\%) @ 45 DAS (88.00) and $\mathrm{T}_{10^{-}}$Moringa leaf extract $(3 \%)$ @ 45 DAS (88.33). Maximum taken days to maturity was recorded by $\mathrm{T}_{0}-$ Control (90.00). The positively effect of spraying treatment on days to maturity was found to be significant and similar finding observed by Das et al., (1996); Patel, (2006); Purbey and Sen, (2005) and Khalifa et al., (2012).

Observed maximum seed yield per plant (90.76 gm) was recorded by $\mathrm{T}_{6}-\mathrm{SA}(10 \mathrm{ppm})$ @ 45 DAS followed byT $9^{-}$Chitosan $(0.5 \%)$ @ 60 DAS (89.80 g), T $2^{-}$DAP (2\%) @ 45 DAS (86.53 g) andT $11^{-}$Ascorbic Acid (50 ppm) @60 DAS (83.75 g). Minimum seed yield per plant was recorded by $\mathrm{T}_{0}-$ Control (63.90 gm). Seed yield per plot (756.30 gm) found to be highest in $\mathrm{T}_{6}$ - SA (10 ppm) @ 45 DAS followed by 9 $^{-}$Chitosan (0.5\%) @60 DAS (741.68 g), T2- DAP (2\%) @ 45 DAS (709.10 g) andT $11^{-}$Ascorbic Acid (50 ppm) @ 60 DAS (698.77 g). Minimum seed yield per plot was recorded by $\mathrm{T}_{0}-$ Control (516.05 gm). The positively effect of spraying treatment on seed yield was found to be significant and similar finding observed by Aftab et al., (2011); Hesami et al., (2012); Krishnamoorthy and Madalageri, (2000); Rohamare et al., (2013) and Prasad et al., (2003).

Table.1 Analysis of variance for 13 growth and yielding attributes in quinoa

\begin{tabular}{|c|c|c|c|c|}
\hline \multirow[t]{2}{*}{ S.No. } & \multirow[t]{2}{*}{ Characters } & \multicolumn{3}{|c|}{ Mean sum of square } \\
\hline & & $\begin{array}{c}\text { Replications } \\
\quad(d \mathbf{f}=2)\end{array}$ & $\begin{array}{l}\text { Treatments } \\
\quad(d f=12)\end{array}$ & $\begin{array}{l}\text { Error } \\
(d f=24)\end{array}$ \\
\hline 1. & Field emergence percentage & 4.41 & $20.06^{*}$ & 4.91 \\
\hline 2. & Plant height at 60 DAS $(\mathrm{cm})$ & 124.89 & $154.43 *$ & 16.14 \\
\hline 3. & Plant height at 90 DAS $(\mathrm{cm})$ & 47.49 & $219.53 *$ & 8.53 \\
\hline 4. & Number of branches per plant & 1.12 & $3.62 *$ & 1.56 \\
\hline 5. & Total number of panicles plant ${ }^{-1}$ & 1.14 & $4.18^{*}$ & 1.59 \\
\hline 6. & Total number of productive panicles plant ${ }^{-1}$ & 0.79 & $4.01 *$ & 1.18 \\
\hline 7. & Days to anthesis & 46.39 & 2.34 & 9.68 \\
\hline 8. & Days to $50 \%$ flowering & 2.15 & $6.91 *$ & 2.96 \\
\hline 9. & Days to maturity & 1.62 & $3.03 *$ & 4.89 \\
\hline 10. & Seed yield per plant $(\mathrm{g})$ & 54.79 & $242.89 *$ & 82.81 \\
\hline 11. & Seed yield per plot $(\mathrm{g})$ & 5303.43 & $16993.21 *$ & 5467.86 \\
\hline 12. & Biological yield & 58908.84 & 8198.37 & 25267.03 \\
\hline 13. & Harvest index & 42.29 & $50.27 *$ & 2.25 \\
\hline
\end{tabular}

* Significant at 5\% level of significance 
Table.2 Mean performance of quinoa for 13 growth and yielding attributes

\begin{tabular}{|c|c|c|c|c|c|c|c|c|c|c|c|c|c|c|}
\hline S.No. & $\begin{array}{c}\text { Treatme } \\
\text { nts }\end{array}$ & $\begin{array}{c}\text { Field } \\
\text { Emergence } \\
\text { percentage }\end{array}$ & $\begin{array}{c}\text { Plant } \\
\text { height at } \\
60 \text { DAS } \\
\text { (cm) }\end{array}$ & $\begin{array}{c}\text { Plant } \\
\text { height } \\
\text { at } 90 \\
\text { DAS } \\
(\mathrm{cm})\end{array}$ & $\begin{array}{c}\text { Number } \\
\text { of } \\
\text { branche } \\
\text { s per } \\
\text { plant }\end{array}$ & $\begin{array}{c}\text { Total } \\
\text { number } \\
\text { of } \\
\text { panicles } \\
\text { plant }^{-1}\end{array}$ & $\begin{array}{c}\text { Total } \\
\text { number of } \\
\text { productive } \\
\text { panicles }^{-1} \text { plant }^{-1}\end{array}$ & $\begin{array}{l}\text { Days to } \\
\text { anthesis }\end{array}$ & $\begin{array}{c}\text { Days to } \\
50 \% \\
\text { flowering }\end{array}$ & $\begin{array}{c}\text { Days to } \\
\text { maturit } \\
y\end{array}$ & $\begin{array}{l}\text { Seed yield } \\
\text { per plant } \\
\text { (g) }\end{array}$ & $\begin{array}{l}\text { Seed yield } \\
\text { per plot } \\
(\mathrm{g})\end{array}$ & $\begin{array}{l}\text { Biologi } \\
\text { cal } \\
\text { yield } \\
(g)\end{array}$ & $\begin{array}{c}\text { Harvest } \\
\text { index }\end{array}$ \\
\hline 1 & $\mathbf{T}_{0}$ & 78.33 & 83.01 & 100.00 & 7.00 & 5.86 & 3.00 & 46.02 & 50.67 & 90.00 & 63.90 & 516.05 & 1199.37 & 43.05 \\
\hline 2 & $\mathbf{T}_{1}$ & 79.67 & 98.00 & 108.00 & 8.00 & 6.37 & 5.01 & 45.42 & 49.33 & 89.67 & 67.33 & 561.10 & 1256.70 & 44.67 \\
\hline 3 & $\mathbf{T}_{2}$ & 85.00 & 99.67 & 120.33 & 9.70 & 9.02 & 6.53 & 44.74 & 46.67 & 88.00 & 86.53 & 709.10 & 1338.94 & 53.31 \\
\hline 4 & $\mathbf{T}_{\mathbf{3}}$ & 81.67 & 90.00 & 123.67 & 7.57 & 7.05 & 4.90 & 45.67 & 50.00 & 89.67 & 78.29 & 652.45 & 1284.74 & 50.82 \\
\hline 5 & $\mathbf{T}_{4}$ & 84.33 & 93.33 & 116.00 & 9.67 & 7.33 & 5.50 & 45.33 & 50.33 & 89.33 & 76.44 & 637.00 & 1280.31 & 49.83 \\
\hline 6 & $\mathbf{T}_{5}$ & 80.00 & 93.00 & 114.00 & 7.67 & 7.38 & 5.23 & 44.67 & 47.33 & 89.67 & 72.28 & 602.30 & 1263.53 & 47.69 \\
\hline 7 & $\mathbf{T}_{6}$ & 87.00 & 106.67 & 127.00 & 10.33 & 9.67 & 7.33 & 43.42 & 46.00 & 86.67 & 90.76 & 756.30 & 1339.48 & 56.68 \\
\hline 8 & $\mathbf{T}_{7}$ & 83.67 & 87.00 & 116.33 & 8.66 & 6.67 & 4.33 & 44.33 & 48.33 & 89.33 & 79.63 & 663.60 & 1261.99 & 52.60 \\
\hline 9 & $\mathbf{T}_{8}$ & 82.33 & 87.02 & 101.00 & 7.32 & 6.50 & 4.67 & 44.07 & 50.00 & 88.67 & 65.96 & 549.65 & 1206.85 & 45.91 \\
\hline 10 & $\mathbf{T}_{9}$ & 85.67 & 98.60 & 125.00 & 10.00 & 9.00 & 7.02 & 44.00 & 47.00 & 87.33 & 89.80 & 741.68 & 1356.53 & 54.95 \\
\hline 11 & $\mathbf{T}_{10}$ & 81.00 & 88.60 & 110.00 & 8.33 & 6.53 & 5.20 & 44.26 & 49.67 & 88.33 & 69.86 & 582.20 & 1239.58 & 46.98 \\
\hline 12 & $\mathbf{T}_{11}$ & 84.00 & 105.00 & 120.67 & 9.30 & 8.15 & 6.10 & 43.33 & 48.67 & 89.00 & 83.85 & 698.77 & 1352.61 & 51.71 \\
\hline 13 & $\mathbf{T}_{12}$ & 81.00 & 92.67 & 115.00 & 8.30 & 7.01 & 5.30 & 45.71 & 49.00 & 89.33 & 73.51 & 612.60 & 1275.16 & 48.05 \\
\hline \multicolumn{2}{|c|}{ Grand Mean } & 82.59 & 94.04 & 115.15 & 8.60 & 7.43 & 5.39 & 44.69 & 48.69 & 88.85 & 76.78 & 637.14 & 1281.22 & 49.71 \\
\hline \multicolumn{2}{|c|}{ C.D. $(5 \%)$} & 3.73 & 6.77 & 4.92 & 2.11 & 2.12 & 1.83 & 5.24 & 2.90 & 3.73 & 15.33 & 124.61 & 267.87 & 2.53 \\
\hline \multicolumn{2}{|c|}{$\mathrm{SE}(\mathrm{m})$} & 1.28 & 2.32 & 1.69 & 0.72 & 0.73 & 0.63 & 1.80 & 0.99 & 1.28 & 5.25 & 12.69 & 91.77 & 0.87 \\
\hline \multicolumn{2}{|c|}{ SE(d) } & 1.81 & 3.28 & 2.38 & 1.02 & 1.03 & 0.89 & 2.54 & 1.40 & 1.81 & 7.43 & 60.38 & 129.79 & 1.22 \\
\hline \multicolumn{2}{|c|}{ C.V. } & 2.68 & 4.27 & 2.54 & 14.53 & 16.98 & 20.14 & 6.96 & 3.53 & 2.49 & 11.85 & 11.61 & 12.41 & 3.02 \\
\hline
\end{tabular}


Biological yield (1356.53 gm) was observed highest in $\mathrm{T}_{9^{-}}$Chitosan $(0.5 \%)$ @ 60 DAS followed by $\mathrm{T}_{11^{-}}$Ascorbic Acid (50 ppm) @ 60 DAS (1352.61 g), T6- SA (10 ppm) @ 45 DAS (1339.48 g) and T2- DAP (2\%)@ 45 DAS (1338.94 g). Minimum biological yield was recorded by $\mathrm{T}_{0}-$ Control (1199.37 gm). The positively effect of spraying treatment on biological yield was found to be nonsignificant and similar finding observed by Ezz El-Din and Khalil, (2004); Naidu and Swamy, (1995) and Giannakoula et al., (2012).

Maximum harvest index (56.68\%)was recorded by $\mathrm{T}_{6}-\mathrm{SA}(10 \mathrm{ppm}) @ 45 \mathrm{DAS}$ followed by $\mathrm{T}_{9-}$ - Chitosan $(0.5 \%) @ 60$ DAS (54.95\%), T $2^{-}$DAP (2\%) @ 45 DAS $(53.31 \%)$ andT $7^{-}$Urea (2\%) @ 60 DAS (1338.94 g).Minimum harvest index was recorded by $\mathrm{T}_{0}-$ Control (43.05\%).The positively effect of spraying treatment on harvest index was found to be significant and similar finding observed by Gomaa, (2001); Narra et al., (2010); Farooqi et al., (1999) and; Rohamare et al., (2013).

On the basis of results obtained from the present experiment following conclusions are drawn. Foliar application treatment increases the germinability and vigour of quinoa seeds, significantly in field condition. Spraying with Salicylic Acid 10 ppm @ 45 DAS followed by Chitosan 0.5\%@60 DAS, DAP 2\%@45 DAS, Ascorbic Acid 50 ppm @60 DAS and Urea $2 \%$ @ 60 DAS showed maximum increase in germinability and vigour of quinoa seeds. Foliar application treatment on field condition give best result in Salicylic Acid 10 ppm @ 45 DAS and found to be lowest in Control (untreated).

These conclusions are based on the results of six months investigation and therefore further investigation is needed to arrive at valid recommendations. The treatments of quinoa crop with Ascorbic Acid is ecofriendly and economic in use.

\section{References}

Abbas, M. K. (2013). Effect of foliar fertilizer and some growth regulators on vegetative and anatomical characters of Dill (Anethum graveolens L.). MiddleEast Journal of Scientific Research, 13(6): 803-811.

Aishwath, O. P., Khurana, H. S., and Anwer, M. M. (2011). A review on the effect of integrated nutrient management on yield and quality of major seed spice crops in India. Better Crops- South Asia, 19-21.

Bate, I. D., Jadhav, B. B., Shmde, A. K. and Mahadik, S. G. (2003). Influence of foliar sprays of growth regulators on growth, herbage and oil yield in patchouli (Pogostemon cablin Benth). National seminar on physiological interventions for improved crop productivity and quality: opportunities and constraints, pp. 142.

Bhat, M. A., Tahir, I., Shahri, W. and Ahmad, S. (2011). Effect of gibberellins and cytokinins on growth and flowering of Iberis umbellata L. National Seminar on Sustainable Crop Productivity through Physiological Interventions, pp.14. Ramnarain Ruia college, Matunga, Mumbai.

El-Keltawi, N. E. and Croteau, R. (1987). Influence of foliar applied cytokinins on growth and essential oil content of several members of the Lamiaceae. Phytochemistry, 26: 891-895.

El-Sherbeny, S. E. and Abou Zeid, E. N. (1986). A preliminary study on the effect of foliar micro elements on growth and chemical constituents in Foeniculum copillacum. Bull. NRC, Egypt, II, pp. 606.

Ezz El-Din, A. A. and Khalil, M. Y. (2004). Effect of foliar fertilization on growth 
and yield of two species of Plantago plant in Egypt. Egypt J. Hort., 30: 227237.

Farooqi, A. H. A., Kumar, R., Sharma, S. and Kumar, S. (1999). Effect of PGRs on flowering behaviour of pyrethrum (Chrysanthemum cinerariaefolium) in north Indian plains. Journal of Medicinal and aromatic Plant Sciences, 21: 681-685.

Gianna, V., Manual Montes, J., Luis Calandri, E. and Alberto Guzman,C., (2012). Impact of several variables on the microwave extraction of Chenopodium quinoa Willd saponins. Intl. J. food Sci. and Technol. 47 (8): 1593-1597.

Hesami, S., Nabizadeh, E., Rahimi, A. and Rokhzadi, A. (2012). Effects of salicylic acid levels and irrigation intervals on growth and yield of coriander (Coriandrum sativum) in field conditions. Environmental and Experimental Biology, 10: 113-116.

Kataria, G. K., Poshiya, V. K., and Chovaiiya, V. P. (2003). Effect of growth regulators on growth and flower yield of Chrysanthemum and Gaillardia. 2nd International Congress of Plant Physiology on Sustainable Plant Productivity under Changing Environment, pp.497.

Khalifa, R. KH. M., Shaaban, S. H. A. and Rawia, A. (2012). Effect of foliar application of zinc sulfate and PGRs on growth, yield and chemical constituents of iris plants. Ozean Journal of Applied Sciences, 4(2): 129-144.

Morales, A., A. Silva, J. Maldonado, and H. Silva. (2017). Transcriptional responses of Chilean Quinoa (Chenopodium quinoa Willd.) under water deficit conditions uncovers ABA-Independent expression patterns. Front. Plant. Sci. 8, 216.

Naidu, C. and Swamy P. (1995). Effect of gibberellic acid on growth, biomass production and associated physiological parameters in some selected tree species. Indian Journal of Plant Physiology, 7: 15-17.

Narra, H., Mamidala, P. and Mehta, P. M. (2010). Gibberellic acid and cycloheximide influenced the growth and biochemical constituents of a medicinally important plant Trachyspermum ammi (L.) Sprague. Current Trends in Biotechnology and Pharmacy, 4(1): 596-603.

Panse V. G., and Sukhatme P. V. (1967). Statistical Methods for Agricultural Workers. Indian Council of Agricultural Research:103-108.

Patel, N. and Vyas, A. V. (2007). Action and interaction of PGRs on growth of Dill, XXIst Gujarat Science Congress convention, Ahmedabad, abstract no. AP-39, pp. 132.

Rathod, R., Siddappa Kannur, Krishna, A. and Vasantha Reddy K. V. (2005). Effect of gibberellic acid treatments on germination and growth of Samania Saman. Karnataka J. Agric. Sci., 18(2): 547-548.

Sivakumar, R., Kalarani, M. K. and Vanangamudi, M. (2002). Effect of growth regulators on earhead characters, partitioning efficiency and grain yield of pearl millet (Penisetum glaucum (L.) R. Br.) hybrid and variety. Madras Agric. J., 89(10-12): 693-695.

Tarraf, S. A., El-Din, K. M.G and Balbaa, L. K. (1999). The response of vegetative growth, essential oil on lemongrass (Cymbopogon citrates Hort.) to foliar application of ascorbic acid, nicotinamide and some micronutrients. Arab universities J. Agric. Sci., 7(1): 247-259.

Valcárcel-Yamany, B. and S. Silva. (2012). Applications of quinoa (Chenopodium quinoa Willd.) and amaranth (Amaranthus spp.) and their influence in 
the nutritional value of cereal based foods. Food Public Health 2(6), 265275. Doi: 10.5923/j. fph.20120206.12.

Vani, V., Shankaraiah, V., Reddy, Y. and Babu, D. (2004). Effect of pre-harvest spray of different growth regulators on growth, yield and quality of baby corn (Zea mays). Indian Journal of Agricultural Sciences, 74 (5): 262-264.

\section{How to cite this article:}

Navyashree, M. S., Bineeta Michael Bara, Garlapati Mohan Krishna, Kusume Bhanu Rajesh and Gopika Jaypal. 2021. Effect of Foliar Nutrient on Growth, Seed Yield and Quality Parameters in Quinoa (Chenopodium quinoa willd.). Int.J.Curr.Microbiol.App.Sci. 10(01): 980-987. doi: https://doi.org/10.20546/ijcmas.2021.1001.119 